\title{
The water resources management problem in Libya
}

\author{
Edawi Wheida \\ Supervisor: Ronny Verhoeven \\ Department of Civil Engineering, Ghent University
}

Public defence: 12 June 2009

In Libya there is a growing awareness of the increasing demand for fresh water while fossil groundwater supply is limited. The water supply situation has become more problematic with the rapidly increasing population and the low rainfall. Hence, soon after the discovery of fresh groundwater in the deserts of southern Libya, the local authorities made huge efforts to address the water deficit problems, mainly through the implementation of "The Great Man-made River Project" to sustain its economy. Especially the agriculture sector is exceeding its traditional supplies. The Libyan authorities have begun to design and install the hydraulic infrastructure needed to withdraw and transport this fossil water to various demand sites along its Mediterranean coast where most of the population lives and where the water is used. There is an over-exploitation of fossil groundwater resources to meet the irrigation demands as a result of adapting a food self-sufficiency policy. The rapid development of agricultural activity, the expansion of irrigated areas and over irrigation practices will lead to more depletion of water resources since most of the country's groundwater resources are non-renewable. The supply-driven approach for water management has demonstrated its inability to deliver a substantial degree of water sustainability on the national Libyan level. Despite the strenuous efforts made by the country, it still faces serious water deficits due to continuously increasing water demands beyond the limits of its available water resources. As pressure on the water supply threatens the country's fossil water resources, an immediate reconsideration of agricultural water extraction is needed and appropriate actions have to be implemented in response to the huge levels of consumption. This policy aims at rescuing the present water situation and at avoiding serious environmental and economic crises. Reorganisation of the water consumption pattern to maintain the country's standard of living and to ensure its economic security for the future generations is drastically required.

Consequently, there is a pressing need to adapt a proper approach to water resources management and to identify in which sectors the available water could be successfully used. A series of options can be developed to investigate this need further, such as:

- Investing in the infrastructure to import water from neighbouring countries;

- Investing in developing fossil water resources for agriculture (like the Great Manmade River);

- Making use of the world market to import agricultural products.

The first option appears to be less realistic both from legal and economic perspectives, specially since fresh water is scarce in the whole region and there is no legal frame- 
work for sharing the water resources between the different countries. The second option is not sustainable in the long run, although there are huge reservoirs of untapped fossil water resources. In the last option Libya would not need to get access to 'real water' but by importing certain agricultural products it would be importing 'virtual water'.

\section{Research aims and objectives}

The Libyan Jamahiriya has experienced severe depletion and pollution as a result of the unavailability of water resources, which has become clearly apparent in several populated locations along the coastal strip. Continuing the present pattern of using these resources causes more stress on their availability and has a major effect on the social, economic and environmental life in the region.

Considering the country's economic situation, its huge surface, the climate conditions, and the scattered population in so many areas all over the country, there is an immediate need for a better water resources policy to maintain an acceptable living standard and to ensure a secure life for future generations.

The individual research objectives are:

- To review and assess the water resources situation in the Libyan Jamahiriya.

- To appraise the existing information available for Libya, including population, groundwater, surface water and non-conventional water resources, and to predict the overall future water demand.

- To review the country's current water management practice, which requires water policy reforms, with emphasis on supply and demand management measures and improvement of the legal and institutional provisions?

- To reconsider the current agricultural water policies in order to minimise local deficits in water resources and to avoid water quality deterioration in the coastal areas.

We begin the thesis with a discussion of the major driving force behind water extraction in Libya. The responses from the government have been to transfer the water from the desert aquifers to the coastal areas and to consider water desalination as a future alternative. In order for the available water resources to be well used there is an urgent need to avoid water resources deterioration.

Therefore, there is a great need to improve the system of the water resources management in Libya. This raises questions concerning the future balance of supply and demand and how this balance can be predicted. In Chapter 2, we review and assess the availability of the conventional (groundwater and surface water) and nonconventional (desalination water and recycled wastewater) water resources in Libya and we define the consumption of water in the agricultural, domestic and industrial sectors.

In Chapter 3, we estimate the future water demand. To do this, it is necessary to process the available data for the purpose of estimating the agricultural, domestic and industrial water demands over a projecting period into the future. Because of the water demand depends directly on the population growth, we consider two possibilities of population growth. These different estimates allow us to compare the available water 
resources that can be made feasible during the projection period. In the same chapter we also estimate different expected levels of water demands in the event that serious measures to reduce water consumption are implemented.

In Chapter 4 we consider water shortages and how to manage water resources in a sustainable manner. We put forward two different approaches, namely water supply management and water demand management. The first approach is aimed at enhancing the availability of the resource in order to adapt it to the demand, which will be on the increase. In order to achieve this, huge water works will have to be set up such as Great Man-made River, wastewater recycling and desalination plants, which will increase the water reserve and, consequently, the supply. Reversibly, the second approach focuses on the impact of people's consumption patterns and proposes the reduction of water demand, so that the pressure on this resource could be decreased, especially in a waterdeficient country such as Libya. In this chapter, we review and examine the actual water legislative actions and water institutions. We also introduce some measurements for saving water, awareness campaigns, pricing policies, modernised infrastructures (with the aim of reducing leakage) and institutional reforms.

This second water resources management approach brings forward the concept of Virtual Water (VW). In Chapter 5, we define virtual water as the water embedded in a product, Le. the water consumed during its process of production. The definition of virtual water allows us in Chapter 5 to introduce the use of this virtual concept and to estimate the national Virtual Water Trade (VWT) balance regarding agricultural goods. It aims at the prospective of using VW as a water-saving alternative to improve water efficiency at the national level.

The concept of virtual water becomes more relevant when it is regarded in relation with virtual water trade (VWT) between different countries, since this concept involves the transfer of water. More precisely, the term VWT can be explained from two distinct angles. One takes the production point of view and the other the consumption point of view. The first approach quantifies virtual water as the real water used in the production of a commodity. This approach is production site specific, as it depends on the production conditions. In the second approach, the virtual water content is defined as the amount of water that would have been required to produce the product where it is used or consumed. Hence, it is consumption site specific. In this sense, it could be attractive for Libya to achieve water security by importing water-intensive products, instead of producing all the water-demanding products domestically.

The framework presented in this Chapter encourages policy makers to promote economic growth, achieving food security and improving the quality of life for citizens. However, the shift from trying to produce to import more goods as described here may be helpful in evaluating policy options within the context of multiple national goals, while recognising water resources constrains and maximising opportunities to gain from international trade.

Chapter 6 addresses water management polices and shows the future challenges, namely the food security and the protection of groundwater systems. We propose a com- 
bined strategy of water transport, rainwater harvesting, and wastewater reuse and desalination, along with a variety of water conservation measures that can take Libya on a more sustainable path for the future.

The thesis concludes with Chapter 7 that highlights some key points concerning the planning and management of water resources systems. It emphasises that our research for sustainable development, the effectiveness of any mechanism derived to reach that goal depends in the end on the quality of individuals interested in pursuing it. 